\title{
Sebaran Warna Kambing Boerka Hasil Persilangan Kambing Boer dengan Kacang
}

\author{
(Color Distribution in Boerka Goat Crossing of Boer Goat Breed with Kacang Goat)
}

\author{
Elieser S, Destomo A \\ Loka Penelitian Kambing Potong, PO Box 1 Sungai Putih,Galang, Sumatera Utara 20585 \\ simonsinulingga@yahoo.com
}

\begin{abstract}
The aim of this research is to know the distribution of Boerka goat color which is the result of cross breed of Boer goat with Kacang was done in 2016 at the Experimental Station of Loka Penelitian Kambing Potong Sei Putih. This research used livestock material of 444 Boerka goats which consists of $153 \mathrm{~F} 1,203 \mathrm{~F} 2$ and $88 \mathrm{~F} 3$. The observed parameters include the color distribution seen on head, neck, body, legs, and tail. The data obtained then tabulated and calculated the frequency of phenotype qualitative properties according to Minkema (1993), then analyzed descriptively. The result showed that the colors that appear in Boerka goats are brown, black and white. Distribution of color on each part of the body has its own distinct and distinctive that are dominated by a mixture of brown and white. The white color has the largest surface area on goat body parts. Many brown color on the neck and head while the white color is on the body, legs and tail. In general, Boerka goats color is a combination of Kacang goat color that spread following the pattern of Boer goat color.
\end{abstract}

Key Words: Boerka Goats, Color Distribution, Color Patterns

\begin{abstract}
ABSTRAK
Penelitian bertujuan untuk mengetahui sebaran warna kambing Boerka yang merupakan hasil persilangan kambing Boer dengan Kacang telah dilakukan pada tahun 2016 di Stasiun Percobaan Loka Penelitian Kambing Potong, Sei Putih. Penelitian menggunakan materi ternak sejumlah 444 ekor kambing Boerka yang terdiri dari 153 ekor F1, 203 ekor F2 dan 88 ekor F3 yang ada pada UPT tersebut. Parameter yang diamati meliputi sebaran warna yang terlihat pada bagian kepala, leher, badan, kaki dan bagian ekor. Data yang diperoleh kemudian ditabulasi dan dihitung frekuensi fenotipe sifat kualitatifnya. Hasil penelitian menunjukkan bahwa warna yang muncul pada kambing Boerka adalah warna cokelat, hitam dan putih. Sebaran warna pada masing-masing bagian tubuh memiliki perbedaan dan ciri tersendiri yang didominasi campuran warna cokelat dan putih. Warna putih memiliki luas permukaan terbesar pada bagian tubuh kambing. Warna cokelat banyak terdapat pada bagian leher dan kepala, sedangkan warna putih terdapat pada bagian badan, kaki dan ekor. Secara umum, kambing Boerka memiliki warna kombinasi antara warna kambing kacang yang menyebar mengikuti pola penyebaran warna kambing Boer.
\end{abstract}

Kata Kunci: Kambing Boerka, Sebaran Warna, Pola Warna

\section{PENDAHULUAN}

Populasi kambing di Indonesia pada tahun 2016 mencapai 19.608.000 ekor, populasi tersebut pada umumnya didominasi oleh kambing Kacang dan Peranakan Ettawah (Ditjen PKH 2016). Kambing Kacang merupakan kambing asli Indonesia yang memiliki tubuh kecil dan pendek, bertelinga tegak dan pendek, berbulu pendek dan berwarna hitam, cokelat dengan campuran putih. Kambing kacang memiliki sifat adaptif yang baik pada berbagai kondisi lingkungan dan memiliki kesuburan dan prolifikasi tinggi. 
Salah satu upaya yang telah dilakukan untuk meningkatkan produktivitas kambing Kacang adalah menyilangkan (cross breeding) dengan pejantan unggul impor yaitu kambing Boer. Kambing Boer merupakan kambing tipe pedaging yang diakui secara luas karena memiliki sifat pertumbuhan yang cepat, kualitas daging yang sangat baik dan memiliki tingkat reproduksi yang tinggi (Greyling 2000; Malan 2000). Selain itu, kambing Boer mempunyai tingkat toleransi yang tinggi terhadap kondisi alam dan tahan atau toleran terhadap penyakit parasit (Mirkena et al. 2010).

Pada umumnya kambing hasil persilangan memiliki keragaman antar individu baik secara fenotipe maupun genotipe. Karakterisasi sifat-sifat kambing Boerka perlu dilakukan untuk dijadikan acuan yang menjadi penciri kambing Boerka, terutama sifat fenotipe yang mudah diamati, salah satunya warna bulu. Pola warna pada kambing berfungsi untuk beradaptasi dengan iklim panas, pemanfaatan wol, upacara adat dan penentuan bangsa ternak (Pakpahan et al. 2016). Warna bulu juga berpengaruh terhadap aktivitas penggembalaan kambing (Kiswanto et al. 2015).

Sponenberg (2004) mengemukakan bahwa tipe dasar pola warna bulu dapat dibedakan menjadi warna yang meliputi seluruh permukaan tubuh sehingga membentuk warna homogen atau heterogen. Pola warna ditentukan oleh gen yang berbeda, tetapi bekerjasama dengan gen warna dasar (Mulliadi 1996). Ciri khas kambing Boer adalah warna cokelat kemerahan pada bagian kepala dan leher (Wu et al. 2006; Casey et al. 1988) dan yang lainnya didominasi oleh warna putih. Kambing Kacang memiliki keragaman warna dan pola warna. Warna yang ditemukan pada kambing kacang adalah cokelat, hitam, putih (Devendra \& Burns 1993) dan abu-abu (Batubara et al. 2006; Wahyuni 2016). Wahyuni (2016) melaporkan bahwa warna yang muncul pada kambing Kacang adalah warna polos, namun ditemukan juga warna tidak polos dengan kombinasi dua warna atau tiga warna.

Tujuan dilakukan penelitian ini adalah mengumpulkan data dan informasi sebaran dan pola warna kambing kambing Boerka yang merupakan hasil persilangan kambing Boer dan Kacang. Data dan informasi tersebut dapat dijadikan sebagai salah satu parameter untuk mencirikan kambing Boerka.

\section{MATERI DAN METODE}

Penelitian ini dilaksanakan pada tahun 2016 di Stasiun Percobaan Loka Penelitian Kambing Potong, Sei Putih. Materi utama dalam penelitian ini adalah 444 ekor kambing Boerka (hasil silangan kambing Boer dan Kacang) terdiri dari tiga generasi yaitu F1 (generasi pertama) sebanyak 153 ekor, F2 (generasi kedua) sebanyak 203 ekor dan F3 (generasi ketiga) sebanyak 88 ekor. Rentang usia antara tiga bulan (lepas sapih) hingga lima tahun. Peubah fenotipe sifat kualitatif yang diamati adalah sebaran warna bulu pada populasi dan individu.

Data hasil penelitian yang diperoleh selanjutnya ditabulasi dan dihitung frekuensi fenotipe sifat kualitatifnya, yaitu jumlah fenotipe yang muncul untuk sifat tertentu dibagi dengan jumlah sampel yang diamati dikali $100 \%$. Selanjutnya dianalisis secara deskriptif.

\section{HASIL DAN PEMBAHASAN}

\section{Warna bulu pada bagian tubuh}

Pola warna bulu pada bagian-bagian tubuh kambing Boerka ditampilkan pada Tabel 1. Warna yang muncul pada kambing Boerka yang diamati adalah warna putih, hitam dan 
Tabel 1. Pola warna bulu pada bagian tubuh kambing Boerka

\begin{tabular}{|c|c|c|c|c|c|c|c|c|}
\hline \multirow{3}{*}{ Generasi } & \multirow{3}{*}{ Bagian tubuh } & \multicolumn{7}{|c|}{ Warna bulu } \\
\hline & & Putih & Hitam & Cokelat & Hitam-putih & Cokelat-putih & Cokelat-hitam & Cokelat-hitam-putih \\
\hline & & \multicolumn{7}{|c|}{ - } \\
\hline \multirow[t]{4}{*}{$\mathrm{F} 1(\mathrm{n}=153)$} & Kepala & $3(1,96)$ & $6(3,92)$ & $20(13,07)$ & $23(15,03)$ & $60(39,22)$ & $10(6,54)$ & $31(20,26)$ \\
\hline & Leher & $8(5,23)$ & $5(3,27)$ & $28(18,3)$ & $23(15,03)$ & $65(42,48)$ & $6(3,92)$ & $18(11,76)$ \\
\hline & Badan & $83(54,25)$ & $1(0,65)$ & $6(3,92)$ & $17(11,11)$ & $38(24,84)$ & $4(2,61)$ & $4(2,61)$ \\
\hline & Kaki & $66(43,14)$ & $1(0,65)$ & $3(1,96)$ & $22(14,38)$ & $54(35,29)$ & $3(1,96)$ & $4(2,61)$ \\
\hline \multirow{4}{*}{$\mathrm{F} 2(\mathrm{n}=203)$} & Leher & $16(7,88)$ & $9(4,43)$ & $44(21,67)$ & $14(6,9)$ & $84(41,38)$ & $16(7,88)$ & $20(9,85)$ \\
\hline & Badan & $91(44,83)$ & $0(0)$ & $17(8,37)$ & $8(3,94)$ & $62(30,54)$ & $6(2,96)$ & $20(9,85)$ \\
\hline & Kaki & $73(35,96)$ & $4(1,97)$ & $15(7,39)$ & $11(5,42)$ & $72(35,47)$ & $6(2,96)$ & $19(9,36)$ \\
\hline & Ekor & $137(67,49)$ & $6(2,96)$ & $29(14,29)$ & $22(10,84)$ & $10(4,93)$ & $12(5,91)$ & $7(3,45)$ \\
\hline \multirow[t]{2}{*}{$\mathrm{F} 3(\mathrm{n}=88)$} & Kepala & $1(1,14)$ & $0(0)$ & $17(19,32)$ & $6(6,82)$ & $50(56,82)$ & $2(2,27)$ & $12(13,64)$ \\
\hline & Ekor & $70(79,55)$ & $0(0)$ & $6(6,82)$ & $0(0)$ & $11(12,5)$ & $1(1,14)$ & $0(0)$ \\
\hline \multirow{5}{*}{$\begin{array}{l}\text { Total } \\
(\mathrm{n}=444)\end{array}$} & Kepala & $8(1,80)$ & $12(2,70)$ & $73(16,44)$ & $47(10,59)$ & $195(43,92)$ & $30(6,76)$ & $79(17,79)$ \\
\hline & Leher & $30(6,76)$ & $14(3,15)$ & $89(20,05)$ & $44(9,91)$ & $194(43,69)$ & $24(5,41)$ & $49(11,04)$ \\
\hline & Badan & $210(47,30)$ & $1(0,23)$ & $26(5,86)$ & $28(6,31)$ & $142(31,98)$ & $11(2,48)$ & $28(6,31)$ \\
\hline & Kaki & $162(36,49)$ & $5(1,13)$ & $20(4,50)$ & $38(8,56)$ & $175(39,41)$ & $9(2,03)$ & $32(7,21)$ \\
\hline & Ekor & $324(72,97)$ & $9(2,03)$ & $53(11,94)$ & $24(5,41)$ & $28(6,31)$ & $19(54,28)$ & $7(1,58)$ \\
\hline
\end{tabular}


cokelat. Pola warna membentuk kombinasi warna polos, warna belang dua warna dan belang tiga warna. Warna polos dan belang muncul pada bagian tubuh mulai dari bagian kepala, leher, badan kaki dan ekor dengan proporsi tertentu.

Pola warna bulu pada bagian-bagian tubuh kambing Boerka terlihat bervariasi (Tabel 1) dengan warna putih dan cokelat banyak terdapat pada beberapa bagian tubuh. Warna belang cokelat-putih banyak terdapat pada bagian kepala $(43,92 \%)$ leher $(43,69 \%)$ dan kaki $(39,41 \%)$, sedangkan warna putih banyak terdapat pada bagian badan $(47,30 \%)$ dan ekor $(72,97 \%)$. Warna lain yang muncul hanya berjumlah sedikit, warna tunggal hitam dan warna tunggal cokelat dengan bagian terbesar pada leher yakni masing-masing 3,15 dan $20,05 \%$, warna belang hitam-putih dan cokelat-hitam terbesar pada bagian kepala masingmasing 10,59 dan 6,76\%, sedangkan belang tiga warna putih-hitam-cokelat terbesar terdapat pada bagian kepala $(17,79 \%)$.

Pada generasi F1 banyak dijumpai kambing dengan warna belang cokelat-putih pada bagian kepala $(39,22 \%)$ dan leher $(42,48 \%)$ sedangkan bagian badan, kaki dan ekor banyak terdapat kambing dengan warna tunggal putih dengan persentasi masing-masing 54,$25 ; 43,14$; dan 76,47\%. Generasi F2 paling banyak ditemukan kambing dengan warna kepala dan leher berwarna belang cokelat-putih dengan persentase 41,87 dan 41,38\%, pada bagian badan dan ekor paling banyak kambing yang memiliki warna tunggal putih, sementara pada bagian kaki jumlah antara kambing yang berwarna campuran cokelatputih $(35,47 \%)$ dan warna tunggal putih $(35,96 \%)$ hampir sama banyak. Untuk generasi F3 kebanyakan kambing memiliki warna belang cokelat-putih pada bagian kepala $(56,82 \%)$, leher $(51,14 \%)$, badan $(47,73 \%)$ dan kaki $(55,68 \%)$ sedangkan warna tunggal polos banyak terdapat pada bagian ekor $(79,55 \%)$.

Pada generasi F3 tidak ditemukan kambing dengan warna tunggal hitam pada masingmasing bagian tubuh, sementara pada kambing Boerka generasi F1 dan F2 terdapat beberapa kambing dengan warna tunggal hitam dengan jumlah yang bervariasi. Warna hitam pada kambing Boerka secara keseluruhan yang membentuk warna tunggal maupun warna campuran pada generasi F3 secara umum memiliki persentase jumlah kambing lebih sedikit dibandingkan dengan kambing Boerka generasi F1 dan F2. Hal ini diduga karena pola warna kambing Boerka pada generasi F3 sudah mulai seragam membentuk warna campuran hitam-putih pada bagian kepala $(6,82 \%)$, leher $(7,95 \%)$, badan $(3,41 \%)$ dan kaki $(5,68 \%)$ sehingga proporsi warna hitam mulai menurun terutama warna tunggal hitam.
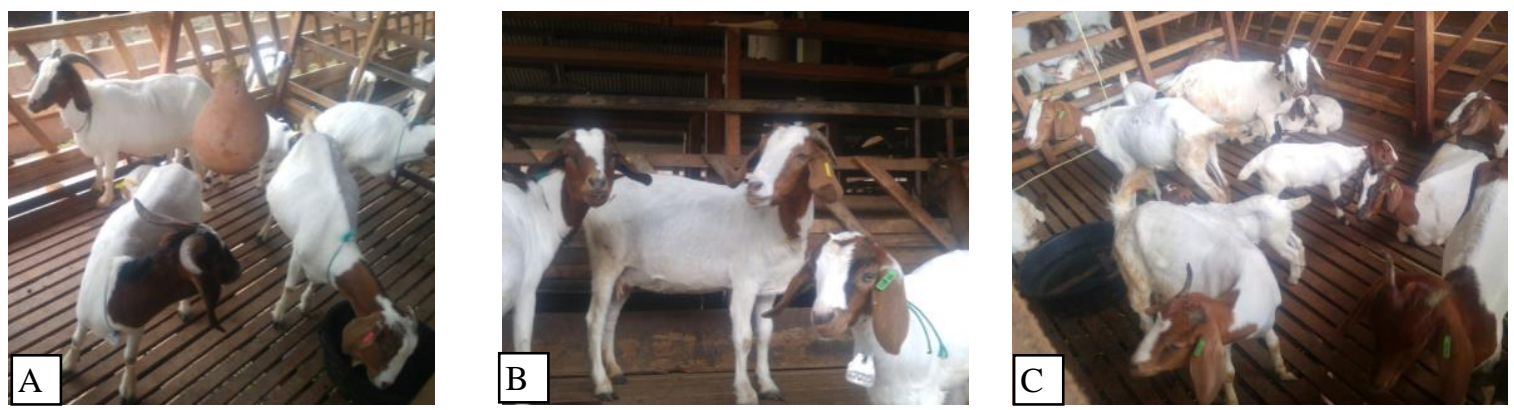

Gambar 1. Kambing Boerka; (A) F1; (B) F2; (C) F3

Pola warna yang muncul pada kambing Boerka diduga merupakan pengaruh gen pembawa sifat fenotipe warna dari kedua tetua yakni kambing Boer dan Kacang, baik membentuk warna tunggal maupun warna campuran dua warna maupun tiga warna. Sebagaimana menurut Mulliadi (1996) pola warna ditentukan oleh gen yang berbeda, tetapi bekerjasama dengan gen warna dasar, demikian pula gen warna dalam pola warna. Berdasarkan luasnya sebaran warna bulu pada kambing Boerka (Tabel 2) menunjukkan bahwa secara total pada ketiga generasi warna Putih $(57,22 \%)$ merupakan warna bulu yang 
paling dominan/luas, kemudian diikuti dengan warna cokelat $(34,76 \%)$ dan permukaan paling kecil adalah warna hitam $(8,27 \%)$. Warna putih pada kambing Boerka rata-rata terdapat pada bagian badan $(77,29 \%)$, kaki $(73,29 \%)$ dan ekor $(78,74 \%)$ sedangkan warna cokelat rata-rata mendominasi bagian kepala $(63,7 \%)$ dan leher $(51,79 \%)$. Warna hitam hanya menempati sedikit permukaan bagian tubuh dengan bagian tubuh paling besar adalah kepala $(16,1 \%)$.

Tabel 2. Luasan warna bulu pada bagian tubuh kambing Boerka

\begin{tabular}{|c|c|c|c|c|c|c|c|}
\hline \multirow{3}{*}{ Generasi } & \multirow{3}{*}{ Warna } & \multicolumn{6}{|c|}{ Bagian Tubuh } \\
\hline & & Kepala & Leher & Badan & Kaki & Ekor & Rata-rata \\
\hline & & \multicolumn{6}{|c|}{----------------------------- $\%$---------------------------- } \\
\hline \multirow[t]{3}{*}{$\mathrm{F} 1(\mathrm{n}=153)$} & Putih & 20,63 & 35,92 & 77,53 & 76,46 & 79,12 & 57,93 \\
\hline & Hitam & 20,22 & 17,88 & 5,97 & 6,92 & 5,10 & 11,22 \\
\hline & Cokelat & 58,95 & 45,82 & 17,01 & 16,41 & 15,89 & 30,82 \\
\hline \multirow[t]{3}{*}{$\mathrm{F} 2(\mathrm{n}=203)$} & Putih & 20,23 & 33,42 & 72,67 & 66,80 & 72,18 & 53,06 \\
\hline & Hitam & 15,57 & 13,78 & 3,79 & 7,52 & 7,14 & 9,56 \\
\hline & Cokelat & 64,66 & 52,75 & 24,27 & 27,08 & 20,78 & 37,91 \\
\hline \multirow[t]{3}{*}{$\mathrm{F} 3(\mathrm{n}=88)$} & Putih & 20,88 & 37,38 & 81,67 & 78,51 & 84,92 & 60,67 \\
\hline & Hitam & 12,50 & 5,35 & 0,52 & 1,63 & 0,23 & 4,05 \\
\hline & Cokelat & 67,51 & 56,78 & 16,86 & 19,86 & 16,78 & 35,56 \\
\hline \multirow[t]{3}{*}{ Rata-rata $(\mathrm{n}=444)$} & Putih & 20,58 & 35,57 & 77,29 & 73,92 & 78,74 & 57,22 \\
\hline & Hitam & 16,10 & 12,34 & 3,43 & 5,35 & 4,15 & 8,27 \\
\hline & Cokelat & 63,70 & 51,79 & 19,38 & 21,12 & 17,82 & 34,76 \\
\hline
\end{tabular}

Jika dilihat dari setiap generasi hasil persilangan kambing Boer dan Kacang, warna putih juga menjadi warna yang memiliki luas permukaan terbesar baik pada generasi $\mathrm{F} 1$ $(57,93 \%)$ maupun pada generasi F2 $(53,06 \%)$ dan F3 $(60,67 \%)$. Sementara untuk warna hitam terjadi penurunan luas permukaan pada setiap generasi. Pada generasi pertama (F1) luas permukaan warna hitam $11,22 \%$ mengalami penurunan pada generasi F2 menjadi 9,56\% dan generasi F3 4,05\%. Sementara warna cokelat luas permukaannya mengalami peningkatan dari generasi pertama (F1) $30,82 \%$ luas permukaan warnanya meningkat menjadi $37,91 \%$ pada generasi $\mathrm{F} 2$ dan $35,56 \%$ pada generasi $\mathrm{F} 3$.

Pola warna yang terdapat pada individu ternak kambing Boerka (Tabel 3), warna belang putih-cokelat memiliki jumlah yang paling banyak $(53,6 \%)$ dari total individu yang diamati. Selanjutnya diikuti dengan jumlah kambing dengan warna belang putih-hitamcokelat $(27,25 \%)$ dan warna putih-hitam $(13,06 \%)$. Pola warna lain memiliki porsi sangat sedikit yakni di bawah 3\%. Pola warna tunggal pada kambing Boerka didapati pada warna putih $(1,13 \%)$ dan cokelat $(2,93 \%)$, sedangkan warna tunggal hitam tidak terdapat pada kambing yang diamati.

Pada ketiga generasi kambing Boerka, warna belang putih-cokelat mendominasi pola warna bulu dengan F2 yang paling banyak dan diikuti F1 lalu F3. Pola warna putih-hitam mengalami penurunan frekuensi dari F1 ke F3, tidak terdapat kambing Boerka yang memiliki warna tunggal hitam pada setiap generasi, sedangkan pola warna lain mengalami kenaikan dan penurunan jumlah. Pada generasi F3 tidak terdapat kambing dengan pola warna tunggal hitam dan hitam-cokelat. 
Tabel 3. Pola warna pada setiap individu kambing Boerka

\begin{tabular}{lrrrr}
\hline & \multicolumn{3}{c}{ Generasi } & \multirow{2}{*}{ Total $(\mathrm{n}=444)$} \\
\cline { 2 - 3 } & \multicolumn{1}{c}{ W1 $(\mathrm{n}=153)$} & $\mathrm{F} 2(\mathrm{n}=203)$ & $\mathrm{F} 3(\mathrm{n}=88)$ & \\
\cline { 2 - 4 } & $2(1,31)$ & $2(0,99)$ & $1(1,14)$ & $5(1,13)$ \\
\hline Putih & $0(0,00)$ & $0(0,00)$ & $0(0,00)$ & $0(0,00)$ \\
Hitam & $2(1,31)$ & $9(4,43)$ & $2(2,27)$ & $13(2,93)$ \\
Putih-Hitam & $31(20,26)$ & $21(10,34)$ & $6(6,82)$ & $58(13,06)$ \\
Putih-Cokelat & $79(51,63)$ & $97(47,78)$ & $62(70,45)$ & $238(53,60)$ \\
Hitam-Cokelat & $2(1,31)$ & $7(3,45)$ & $0(0,00)$ & $9(2,03)$ \\
Putih-Hitam-Cokelat & $37(24,18)$ & $67(33,00)$ & $17(19,32)$ & $121(27,25)$ \\
\hline
\end{tabular}

\section{KESIMPULAN}

Warna yang muncul pada kambing persilangan Boer dan Kacang (Boerka) adalah warna putih, cokelat dan hitam. Pola warna kambing Boerka didominasi oleh campuran warna cokelat dan putih. Warna bulu yang paling luas permukaanya adalah warna putih yang tersebar pada bagian badan, kaki dan ekor sedangkan bagian kepala dan leher didominasi campuran warna putih dan coeklat. Warna bulu pada kambing persilangan Boer dan Kacang menyerupai kedua bangsa induknya. Warna bulu yang menjadi penciri kambing Boerka secara umum adalah campuran putih dan cokelat.

\section{DAFTAR PUSTAKA}

Batubara A, Doloksaribu M, Tiesnamurti B. 2006. Potensi keragaman sumberdaya genetik kambing lokal Indonesia. Dalam: Lokakarya Nasional Pengelolaan dan Perlindungan Sumber Daya Genetik di Indonesia: Manfaat Ekonomi untuk Mewujudkan Ketahanan Nasional. Bogor, 20 Desember 2016. Bogor (Indonesia): Puslitbangnak. hlm. 206-14.

Casey NH, Niekerk WAV. 1988. The Boer goat. I. Origin, adaptability, performancetesting, reproduction and milk production. Small Rum Res. 1:291-302.

Devendra C, Burns M. 1983. Goat production in the tropics. Slough (UK): CAB, Farnham House.

Ditjen PKH. 2016. Statistik peternakan 2016. Jakarta (Indonesia): Direktorat Jenderal Peternakan dan Kesehatan Hewan, Kementerian Pertanian

Greyling JPC. 2000. Reproduction traits in the Boer goat doe. Small Rum Res. 36:171-177

Indrijani H, Sukmasari AH, Handiwirawan E. 2006. Keragaman pola warna tubuh, tipe telinga dan tanduk domba kurban di Bogor. Dalam: Manfaat Ekonomi Untuk Mewujudkan Ketahanan Nasional. Prosiding Lokakarya Nasional Pengelolaan dan Perlindungan Sumber Daya Genetik di Indonesia. Bogor (Indonesia): Puslitbangnak.

Kiswanto SH, Baihaqi M, Prihantoro I. 2015.Grazing behavior and itineraries of Kacang goat with different coat color under semi intensive management.Anim Prod. 172:107-113.

Malan SW. 2000. The improved Boer goat. Small Rum. Res. 36:165-170.

Mirkena T, Duguma G, Haile A, Tibbo AM, Okeyo M, Wurzinger M, SolknerJ. 2010. Genetics of adaptation in domestic farm animal: A review. Livest Sci. 132:1-12.

Mulliadi D. 1996. Sifat fenotipik domba Priangan di Kabupaten Pandeglang dan Garut [Disertasi]. [Bogor (Indonesia)]: Institut Pertanian Bogar. 
Noor RR. 2008. Genetika ternak. Edisi ke-4. Jakarta (Indonesia): Penebar Swadaya.

Pakpahan S, Widayanti R, Artama WT, Budisatria IGS. 2016. Copy number variation of agouti signaling protein (ASIP) fragment and its relationship with coat color in Indonesian goat breeds. Asian J Anim Vet Adv. 11:701-708.

Sponenberg P. 2004. Genetics of goat color. Blacksburg (US): Virginia-Maryland Regional College of Veterinary Medicine, Virginia Polytechnic Institute and State University, Blacksburg.

Wahyuni V, Nafiu L, Pagala MA. 2016. Karakteristik fenotipe kualitatif dan kuantitatif kambing Kacang di Kabupaten Muna Barat. JITRO. 1:144-156.

Wu ZL, Li XL, Liu YQ, Gong YF, Liu ZZ, Wang XJ, Xin TR, Ji Q. 2006. The red head and neck of Boer goats may be controlled by the recessive allele of the MC1R gene. Anim Res. 55:313322

\section{DISKUSI}

\section{Pertanyaan}

1. Apakah itu kambing Boerka?

2. Apakah ada pengaruh antara sifat warna bulu dengan produksi kambing Boerka?

3. Bagaimana cara mengukur luasan warna bulu pada kambing Boerka?

\section{Jawaban}

1. Kambing Boerka adalah persilangan antara kambing Boer jantan dengan kambing Kacang betina.

2. Tidak ada kaitan secara langsung antara sifat warna bulu dengan produktivitas kambing Boerka, hanya sebagai penciri kepada jenis kambing tertentu. Kaitan warna dengan produksi hanya sedikit, yakni mempengaruhi tingkah laku pada penggembalaan kambing.

3. Mengukur luasan warna bulu adalah dengan metode dokumentasi. Yakni dengan menggunakan hasil cetakan gambar kambing dari berbagai sisi, selanjutnya diukur dengan kotak-kotak berukuran 0,5 cm pada bidang transparan. Warna bulu yang tercover oleh kotak-kotak dihitung dan dikonversi kehitungan persen (\%). 